\title{
Nitrogen Removal from Piggery Wastewater within a Sequencing Batch Reactor Using Pseudomonas putida
}

\author{
Yunlong Yang, Feixue Chen, Linxiang Xie, Jun Xiong, Kaihui Hu* \\ College of life science, Fujian Agriculture and Forestry University, Fuzhou 350002, China
}

Received: 18 August 2016

Accepted: 15 October 2016

\begin{abstract}
This work evaluates the efficiency of ammonium removal from piggery wastewater using a sequencing batch reactor (SBR) inoculated with a newly isolated strain of Pseudomonas putida HJH1. The strain HJH1 not only could survive and remove up to $72.4 \mathrm{mg} / \mathrm{L} \mathrm{NO}_{2}^{-}-\mathrm{N}$ under aerobic conditions, but it also has good performance for simultaneous nitrification and denitrification (SND) with no nitrite accumulation. The SBR system was able to consistently remove: 1) $76.4-100 \%$ ammonium nitrogen and $71.4-100 \%$ COD from artificial wastewater in stage 1, and 2) 89.2-99.1\% ammonium nitrogen and 82.4-100\% COD from piggery wastewater in stage 2. During the whole operation, the strain HJH1 predominated in the SBR all the time to function together with other bacteria. Results indicated that the SBR system inoculated with Pseudomonas putida $\mathrm{HJH} 1$ can efficiently remove ammonium nitrogen from piggery wastewater, thereby having potential applications for future nitrogen removal.
\end{abstract}

Keywords: nitrogen removal, piggery wastewater, Pseudomonas putida, sequencing batch reactor, simultaneous nitrification and denitrification

\section{Introduction}

Due to increasingly serious eutrophication, removal of nitrogen from discharged wastewater has been required in many wastewater treatment plants, and a variety of methods have been set up, among which simultaneous nitrification and denitrification (SND) has become an attractive technology for nitrogen removal. SND not only means that nitrification and denitrification occur concurrently in the same reaction vessel under identical operating conditions, but also implies that nitrite and ammonium could be removed simultaneously, both of

*e-mail: 474585312@qq.com which are important factors affecting the environment.

Nitrite plays a critical role in the nitrogen-cycle of the ecosystem. However, its accumulation in the water becomes increasingly intense as a result of rapid development in the fields of aquaculture, agriculture, and industry in recent years, which makes nitrite become a matter of great concern for the environment. For example, the toxicity of nitrite could cause a fish disease outbreak that leads to huge economic losses [1$2]$. Therefore, it becomes extremely necessary to decrease the accumulation of nitrite in the water. In general, there are three methods involved in nitrite removal: physical [3], chemical [4], and biological [5]. Of them, the best is the biological method without secondary pollution and residues. According to the traditional denitrification 
theory, the denitrifying process is limited to anaerobic conditions, but aerobic denitrification has attracted more and more attention due to some advantages [6]. The first aerobic denitrifier was reported to be the Thiosphaera pantotropha strain [7] (now reclassified as Paracoccus denitrifican) in 1984. Following this pioneering work, some other new aerobic denitrifiers belonging to genera such as Pseudomonas, Alcaligenes, and Bacillus were also isolated [8-10], and more and more isolates were applied to the nitrogen removal system.

Ammonium is also an important factor contributing to eutrophication. In view of containing a high concentration of ammonium, effective treatment of piggery wastewater will improve the local environment - especially in China and many other developing countries. Statistically, the recorded piggery wastewater discharged to the environment was more than $1.1 \times 10^{7}$ tons in 2014 [11]. Since these pollutants become heavy burdens to the environment, various biological methods have been developed, such as anaerobic bioreactors [12], membrane bioreactors [13], and upflow microaerobic sludge reactors [14]. Moreover, the sequencing batch reactor (SBR), owing to its characteristics of easy operation and high efficiency, is also widely used in the treatment of piggery wastewater [15-17]. However, the SBR in which a functional microorganism is inoculated to remove ammonium from piggery wastewater was rarely reported [18].

Some studies have revealed that strains capable of heterotrophic nitrification and aerobic denitrification existed, such as Acinetobacter calcoaceticus [19], Pseudomonas stutzeri [8], Halomonas campisalis [20], Chelatococcus daeguensis [21], and Bacillus [10]. These strains can oxidize ammonium to nitrite and, simultaneously, reduce nitrite to $\mathrm{N}_{2}$ by way of the aerobic denitrification function, meaning that high efficiency of treating piggery wastewater by inoculating these strains into bioreactors to strengthen the SND process could be obtained. Although the aerobic denitrification by Pseudomonas putida [22-23] was well documented, its SND potential for ammonium removal from piggery wastewater has not yet been explored.

Therefore, in this study a bacterium strain for SND was isolated and identified. Its nitrogen removal performance was investigated step by step, including: 1) nitrite removal capability from denitrification medium in shaking flasks and a bioreactor, and 2) ammonium removal capability from piggery wastewater in an SBR, which aims to determine whether the augmentation of Pseudomonas putida could successfully improve SND performance to enhance nitrogen removal in an SBR system for piggery wastewater treatment.

\section{Materials and Methods}

\section{Media}

The screening medium $(\mathrm{SCM})$ consisted of $(\mathrm{g} / \mathrm{L})$ : $\mathrm{NaNO}_{2}, 0.1 ; \mathrm{KH}_{2} \mathrm{PO}_{4}, 0.5 ; \mathrm{FeCl}_{2} \cdot 6 \mathrm{H}_{2} \mathrm{O}, 0.05 ; \mathrm{CaCl}_{2}, 0.02$;
$\mathrm{MgSO}_{4} \cdot 7 \mathrm{H}_{2} \mathrm{O}, 0.5$; sodium citrate, 0.3 ; and $1 \mathrm{ml}$ of trace element solution. The trace element solution was composed of $(\mathrm{g} / \mathrm{L}): \mathrm{FeSO}_{4} \cdot 7 \mathrm{H}_{2} \mathrm{O}, 3 ; \mathrm{H}_{3} \mathrm{BO}_{3}, 0.01 ; \mathrm{Na}_{2} \mathrm{MoO}_{4} \cdot 2 \mathrm{H}_{2} \mathrm{O}$, $0.01 ; \mathrm{MnSO}_{4} \cdot \mathrm{H}_{2} \mathrm{O}, 0.02 ; \mathrm{CuSO}_{4} \cdot 5 \mathrm{H}_{2} \mathrm{O}, 0.01 ; \mathrm{ZnSO}_{4}$, 0.01 ; and ethylene diamine tetraacetic acid (EDTA), 0.5 . The screening medium plate (SMP) was the same as SM besides containing $20 \mathrm{~g} / \mathrm{L}$ agar. The seed medium (SEM) modified from Merk medium was as follows $(\mathrm{g} / \mathrm{L})$ : peptone, $8.6 ; \mathrm{NaCl}, 6.4$; sodium citrate, 1.5 ; and potassium nitrate, 1.5 . The aerobic denitrification medium (DM) comprised $(\mathrm{g} / \mathrm{L})$ : sodium citrate, $4 ; \mathrm{KH}_{2} \mathrm{PO}_{4}, 0.5$; $\mathrm{Na}_{2} \mathrm{HPO}_{4} \cdot 7 \mathrm{H}_{2} \mathrm{O}, 1 ; \mathrm{FeSO}_{4} \cdot 7 \mathrm{H}_{2} \mathrm{O}, 0.1 ; \mathrm{MgSO}_{4}, 0.2$; trace element solution, $2 \mathrm{~mL}$; and an appropriate amount of sodium nitrite. The SND medium (SNDM) was almost the same as DM except that sodium nitrite was replaced with ammonium chloride when used. All media had $\mathrm{pH}$ maintained at 7.0-7.5 and were autoclaved at $115^{\circ} \mathrm{C}$ for $20 \mathrm{~min}$

\section{Experimental Wastewater Characteristics}

The raw piggery wastewater was collected from a local pig farm in Fuzhou, China. Since piggery wastewater is a typical high-strength ammonium $\left(\mathrm{NH}_{4}^{+}-\mathrm{N}\right)$ wastewater, artificial wastewater was used and injected into the SBR prior to piggery wastewater with the aim of making Pseudomonas putida adapt to the ammonium environment in the SBR gradually. On day 19 we used a six-fold dilution of piggery wastewater. On days 20 and 21 we injected a two-fold dilution of piggery wastewater into the SBR. Raw piggery wastewater was used from day 22 on. The experimental wastewater characteristics are shown in Table 1.

\section{Screening of Aerobic Denitrifiers and its Identification}

Aerobic denitrifying organisms were enriched from Guanyin Lake (sometimes eutrophication is high) in Fujian Agriculture and Forestry University, Fu Zhou, China. The water samples were transferred to $100 \mathrm{~mL}$ SCM in $200-\mathrm{mL}$ flasks with eight layers of gauze. The flasks were incubated in a shaking incubator at $180 \mathrm{rpm}$ and $30^{\circ} \mathrm{C}$ for three days. Then a $5 \%$ (volume ratio) of bacteria suspension was

Table 1. Qualities of experimental wastewater characteristics.

\begin{tabular}{|c|c|c|}
\hline Item $(\mathrm{mg} / \mathrm{L})$ & Artificial wastewater & Piggery wastewater \\
\hline $\mathrm{COD}$ & $424-576$ & $1,200-1,528$ \\
\hline $\mathrm{NH}_{4}{ }^{+}-\mathrm{N}$ & $29.1-38.7$ & $227.3-274.5$ \\
\hline $\mathrm{TN}$ & $29.5-39.2$ & $297.6-349.7$ \\
\hline $\mathrm{NO}_{2}^{-}-\mathrm{N}$ & $\mathrm{ND}$ & $\mathrm{ND}$ \\
\hline $\mathrm{NO}_{3}-\mathrm{N}$ & $\mathrm{ND}$ & $\mathrm{ND}$ \\
\hline $\mathrm{pH}$ & $7-8$ & $6-9$ \\
\hline
\end{tabular}

ND: not detected 
added to freshly autoclaved SCM and cultured at $30^{\circ} \mathrm{C}$. After $24 \mathrm{~h}$, the suspension was diluted via gradient and the diluent was streaked on the SMP and incubated at $30^{\circ} \mathrm{C}$ for three days. Prominent growing single colonies were then inoculated to $20 \mathrm{~mL}$ of SEM and incubated at $180 \mathrm{rpm}$ for $16 \mathrm{~h}$. The resultant cellular suspension (2.5 mL) was inoculated to $50 \mathrm{~mL} \mathrm{SCM}$ and cultured for another $48 \mathrm{~h}$. Through measuring the concentration of $\mathrm{NO}_{2}^{-}-\mathrm{N}$, we selected isolates with removal efficiency of more than $80 \%$. This screening process was repeated three times. Only one strain was finally isolated, which was named HJH1.

The HJH1 isolate obtained was maintained at $4^{\circ} \mathrm{C}$ in a plate containing SEM for short-term use and stored at $-20^{\circ} \mathrm{C}$ in $30 \%$ glycerol for long-term use.

Identification of the isolated strain was determined by 16S rRNA gene sequences. The genomic DNA of HJH1 was extracted using a DNA isolation kit (Biotech, Beijing, China). The 16S rRNA gene was amplified by polymerase chain reaction (PCR) with universal bacterial primers (27F: AGAGTTTGATCATGGCTCAG and 1492R: GGTACCTTGTTACGACTT) on a Mastercycler gradient thermocycler (Eppendorf, Germany). $20 \mu \mathrm{l}$ of PCR reaction mixture was used: $2 \mu \mathrm{l}$ of $10 \times \mathrm{PCR}$ buffer, $1.6 \mu \mathrm{l}$ of dNTP mixture, $0.4 \mu \mathrm{l}$ of each primer, $0.5 \mathrm{ng}$ of DNA template, $0.5 \mathrm{U}$ of Tag DNA polymerase (Takara, Dalian, China), and $14 \mu 1$ double-distilled water. The amplification protocol was as follows: predenaturation at $94^{\circ} \mathrm{C}$ for three min, followed by 30 cycles of denaturation at $94^{\circ} \mathrm{C}$ for $30 \mathrm{sec}$, annealing at $55^{\circ} \mathrm{C}$ for $45 \mathrm{sec}$ and elongation at $72^{\circ} \mathrm{C}$ for two min, with a final extension at $72^{\circ} \mathrm{C}$ for $10 \mathrm{~min}$. The PCR product was sequenced by Sangon Biotech (Shanghai, China). The resultant sequence was examined in the Genebank database through the BLAST program to search for the closet matching sequences. Then the phylogenetic tree was constructed with MEGA 4 using the maximum parsimony algorithm.

\section{Preliminary Experiments for HJH1 Nitrogen Removal}

The effects of $\mathrm{pH}$, carbon sources, temperature, and initial $\mathrm{NO}_{2}^{-}-\mathrm{N}$ concentrations on $\mathrm{HJH} 1$ denitrification characteristics were conducted in flasks. A single colony in a plate was inoculated into $30 \mathrm{~mL}$ SEM in a $100-\mathrm{mL}$ flask cultured at $30^{\circ} \mathrm{C}$ for $12 \mathrm{~h}$ in a shaker at $180 \mathrm{rpm}$. Then $5 \%$ (volume ratio) of cellular culture was transferred to $100 \mathrm{ml} \mathrm{DM}$ in a $250-\mathrm{mL}$ flask incubated at $30^{\circ} \mathrm{C}$ for $24 \mathrm{~h}$ in a shaker at $180 \mathrm{rpm}$. Samples were periodically taken out and stored at $-20^{\circ} \mathrm{C}$.

Denitrification performance of HJH1 under optimal conditions was carried out in a bioreactor (Peiqing, Shanhai, China). This column bioreactor (with a maximum volume of $5 \mathrm{~L}$ ) was equipped with an aerator, a dissolved oxygen (DO) monitor (the unit of DO is percentage, which can be transferred to $\mathrm{mg} / \mathrm{L}$ ), and a $\mathrm{pH}$ and temperature control system. The seed culture $(150 \mathrm{~mL})$ was inoculated into $3 \mathrm{~L} \mathrm{DM}$ in the bioreactor and incubated at an aeration rate of $0.8 \mathrm{~L} / \mathrm{min}$ and stirring rate of $200 \mathrm{rpm}$. The initial
$\mathrm{NO}_{2}^{-}-\mathrm{N}$ concentration, $\mathrm{pH}$, and temperature were selected on the basis of the above experiments. Samples were periodically taken out and stored at $-20^{\circ} \mathrm{C}$.

SND performance of HJH1 was conducted in shaking flasks. A single colony on a plate was inoculated into $30 \mathrm{~mL}$ SEM in a $100-\mathrm{mL}$ flask cultured at $30^{\circ} \mathrm{C}$ for $12 \mathrm{~h}$ in a shaker at $180 \mathrm{rpm}$. Then, a 5\% (volume ratio) of cellular culture was transferred to $100 \mathrm{ml} \mathrm{SNDM}$ in a $250-\mathrm{mL}$ flask incubated at $30^{\circ} \mathrm{C}$ for $24 \mathrm{~h}$ in a shaker at $180 \mathrm{rpm}$. Samples were periodically taken out and stored at $-20^{\circ} \mathrm{C}$.

\section{SBR Device and Operation}

A device with a working volume of $1.5 \mathrm{~L}$ was used as the sequencing batch reactor, which is illustrated in Fig. 1. The SBR temperature was controlled at $30^{\circ} \mathrm{C}$ by a temperature control heater, and the airflow rate was controlled by a gas flow meter through which gas was diffused into the reactor using an aerator installed at the bottom of the SBR. The device was operated at a circle time of $6 \mathrm{~h}$, consisting of a 2-min feeding, a 240-min aerobic reaction, and a 30-min settling, followed by a 3-min decanting and an 85-min idle period.

The whole operation period was composed of stages 1 and 2 . In stage 1 , the volumetric exchange ratio was $100 \%$. In order to make $P$. putida predominant in this stage, the pure P. putida culture of $5 \%$ (volume ratio) was inoculated into the artificial wastewater in the reactor. After settling, all cultures were centrifuged at 5,000 rpm for $10 \mathrm{~min}$ and then pallets were all transferred to the reactor to start the next circle. In stage 2, piggery wastewater was injected into the SBR, and volumetric exchange ratio was maintained at $30 \%$. The dissolved oxygen concentration during all stages was controlled at $2.5-4.0 \mathrm{mg} / \mathrm{L}$.

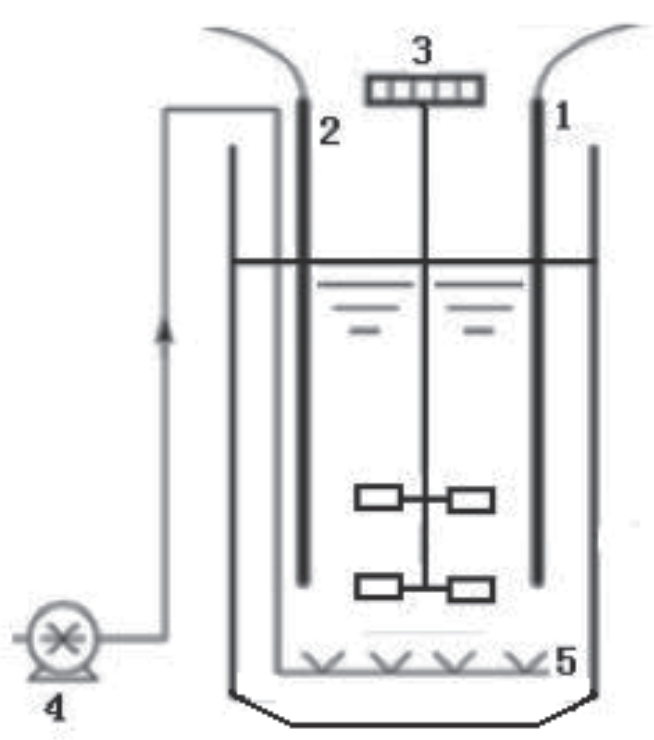

Fig. 1. Schematic diagram of the sequencing batch reactor: 1 . $\mathrm{pH}$ meter, 2. temperature control heater, 3. stirrer, 4. air pump, and 5 . aerator. 


\section{Polymerase Chain Reaction and Denaturing Gradient Gel Electrophoresis}

Polymerase chain reaction and denaturing gradient gel electrophoresis (PCR-DGGE) was conducted on the cultures in SBR. The genomic DNA, extracted as described at section 2.3, was used as a template to amplify 16sRNA genes. PCR was performed in a Mastercycler gradient (Eppendorf 5331, Germany) using the following primers: GC341F (5'-CGC CCG CCG CGC CCC GCG CCC GGC CCG CCG CCC CCG CCC G CCT ACG GG A GGC AGC AG-3') and 907R (5'-CCG TCA ATT CCT TTG AGT TT-3'). DGGE was carried out in a Universal Mutation Detection System (BIO-RAD DCodeTM, USA). The gel contained a gradient of denaturant ranging from $30 \%$ to $60 \%$ (100\% denaturant is $7 \mathrm{M}$ urea and $40 \%$ deionized formamide). DGGE was run at $200 \mathrm{~V}$ for $5 \mathrm{~h}$ at $60^{\circ} \mathrm{C}$. After electrophoresis, the gel was stained with GoldView II (Solarbio, Beijing, China) for $30 \mathrm{~min}$ and viewed with a UV transilluminator (BIO-RAD, Italy).

\section{Analytical Methods}

Total nitrogen (TN), ammonium nitrogen $\left(\mathrm{NH}_{4}^{+}-\mathrm{N}\right)$, nitrite nitrogen $\left(\mathrm{NO}_{2}-\mathrm{N}\right)$, nitrate nitrogen $\left(\mathrm{NO}_{3}-\mathrm{N}\right)$, and COD were analyzed using Standard Methods [24]. DO and $\mathrm{pH}$ were determined online. All samples were filtered except for $\mathrm{TN}$ before analysis.

\section{Results and Discussion}

\section{Phylogenetic Analysis of Aerobic Denitrifier HJH1}

Based on maximum parsimony, a phylogenetic tree prepared using the HJH1 gene fragment and Genebank database sequences was displayed in Fig. 2. The isolate HJH1 showed the most similarity (99\%) with Pseudomonas putida, which had been characterized before as an aerobic denitrifier with an ability to remove nitric oxide [22] and nitrate $[23,25]$.

\section{Effects of Different Factors on HJH1 Nitrite Removal}

Fig. 3 showed the effects of different factors on $\mathrm{HJH} 1$ nitrite removal and cell growth. At $30^{\circ} \mathrm{C} \mathrm{NO}_{2}{ }^{-} \mathrm{N}$ concentration of $55.8 \mathrm{mg} / \mathrm{L}$ was reduced completely in $21 \mathrm{~h}$, and at $37^{\circ} \mathrm{C}$ about $51 \mathrm{mg} / \mathrm{L} \mathrm{NO}_{2}^{-}-\mathrm{N}$ was removed in $24 \mathrm{~h}$ (Fig. 3a). However, both cell growth and nitrite removal were poor at $20^{\circ} \mathrm{C}$. At 20,30 , and $37^{\circ} \mathrm{C}$, maximum cell density $\left(\mathrm{OD}_{600}\right)$ achieved $0.3,0.52$, and 0.47 , and corresponding nitrite removal efficiency was $40.8 \%, 100 \%$, and $92.2 \%$, respectively. Undoubtedly, the optimum temperature for $\mathrm{HJH} 1$ denitrification is $30^{\circ} \mathrm{C}$.

Clearly, there was almost no change in both cell growth and nitrite removal at $\mathrm{pH} 5$ and 6 (Fig. 3b). Although nitrite was consumed completely in $24 \mathrm{~h}$ at $\mathrm{pH} 8,9$, and 10 , their cell growths all had a long lag phase (about $12 \mathrm{~h}$ ), which was mainly attributed to the adaptability of the cell to high $\mathrm{pH}$ conditions. At $\mathrm{pH} 7$, cell density and nitrite removal efficiency reached 0.41 and $100 \%$ in $24 \mathrm{~h}$, respectively, and therefore the optimum $\mathrm{pH}$ for $\mathrm{HJH} 1$ denitrification is 7 .

The selected carbon sources were sodium citrate, sodium succinate, sodium acetate, and glucose. Out of them, sodium citrate contributed to the best cell density and nitrite removal efficiency, which got up to 0.6 and $100 \%$, respectively (Fig. 3c). By contrast, glucose was bad for the strain $\mathrm{HJH} 1$, because both cell density and nitrite removal did not have significant change. Although it has been confirmed that carbon sources exert an important influence on denitrification, these influences vary with

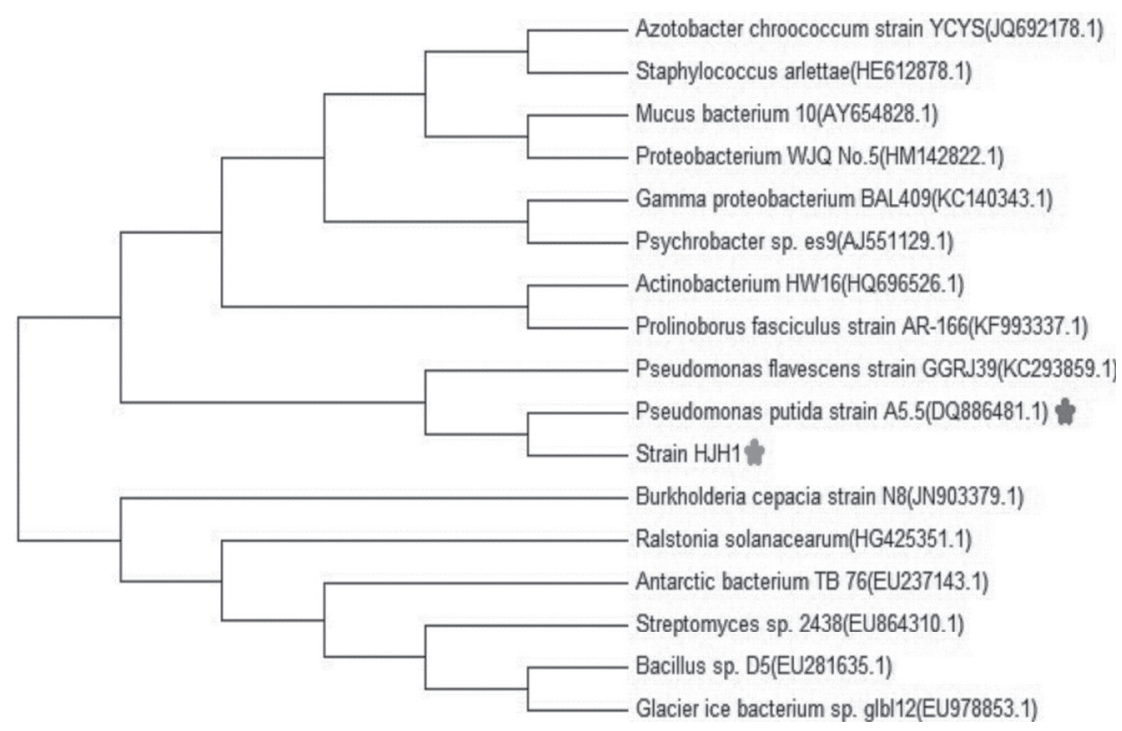

Fig. 2. Phylogenetic tree for aerobic denitrifier HJH1. Identification of the isolated strain was determined by $16 \mathrm{~S}$ rRNA gene sequences and the phylogenetic tree was constructed with MEGA 4 using the maximum parsimony algorithm. 
a)

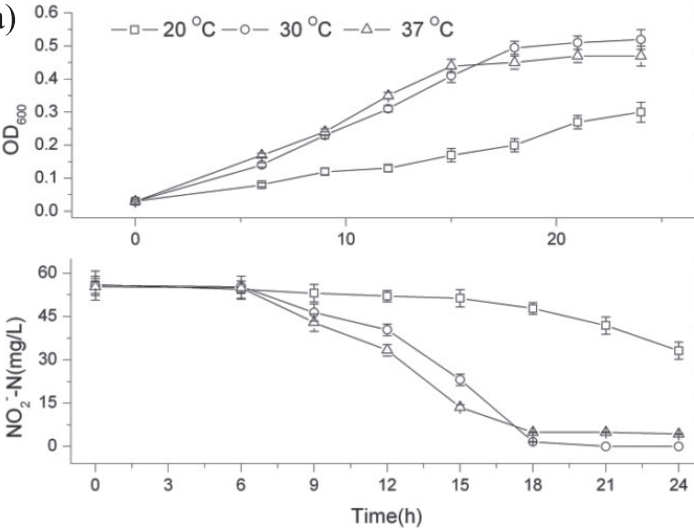

c) $\left.{ }^{0.7}\right]-\square-$ Sodium citrate $-0-$ Glucose

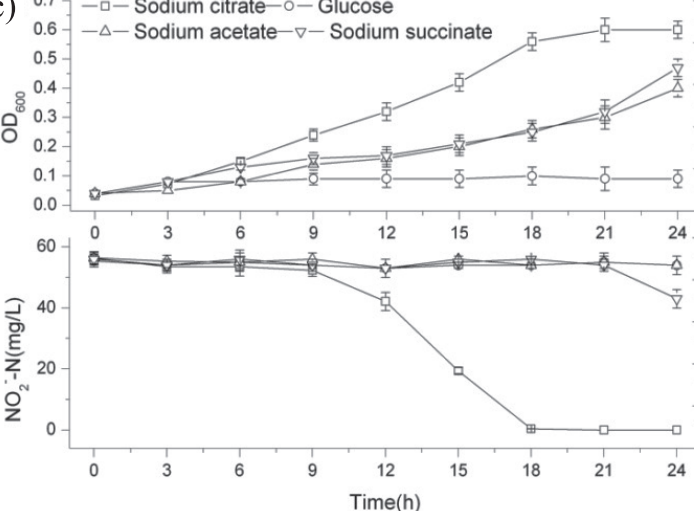

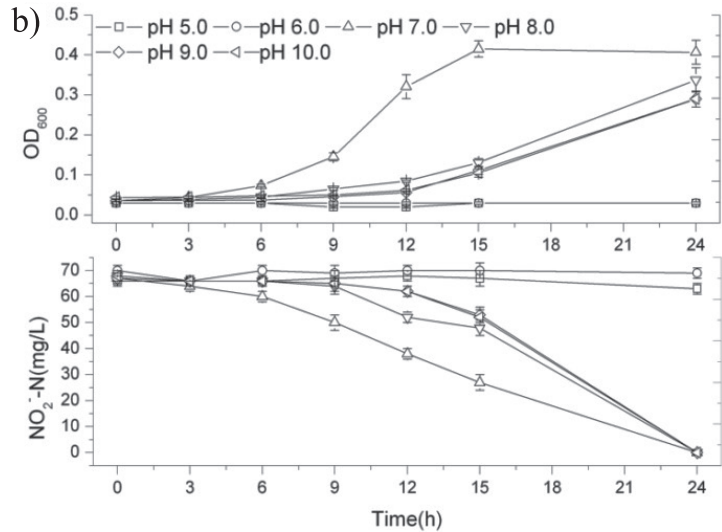

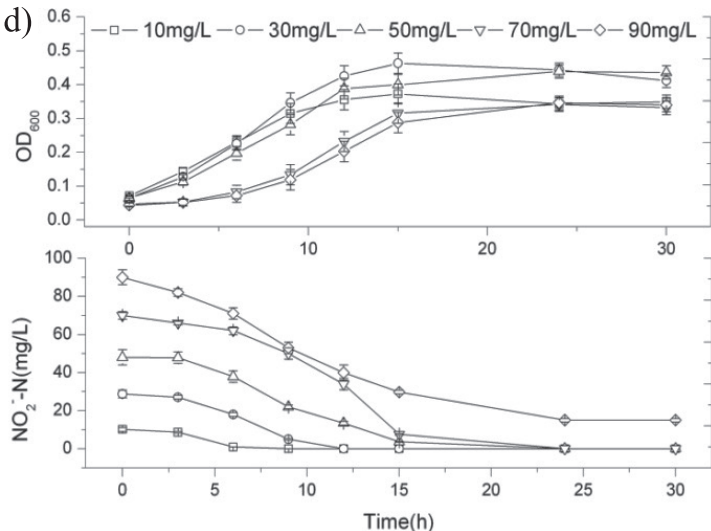

Fig. 3. Effects of different factors on HJH1 characteristics of nitrite removal in flasks: a) Temperature, b) pH, b) Carbon sources, and d) Initial nitrite-N concentration.

a)
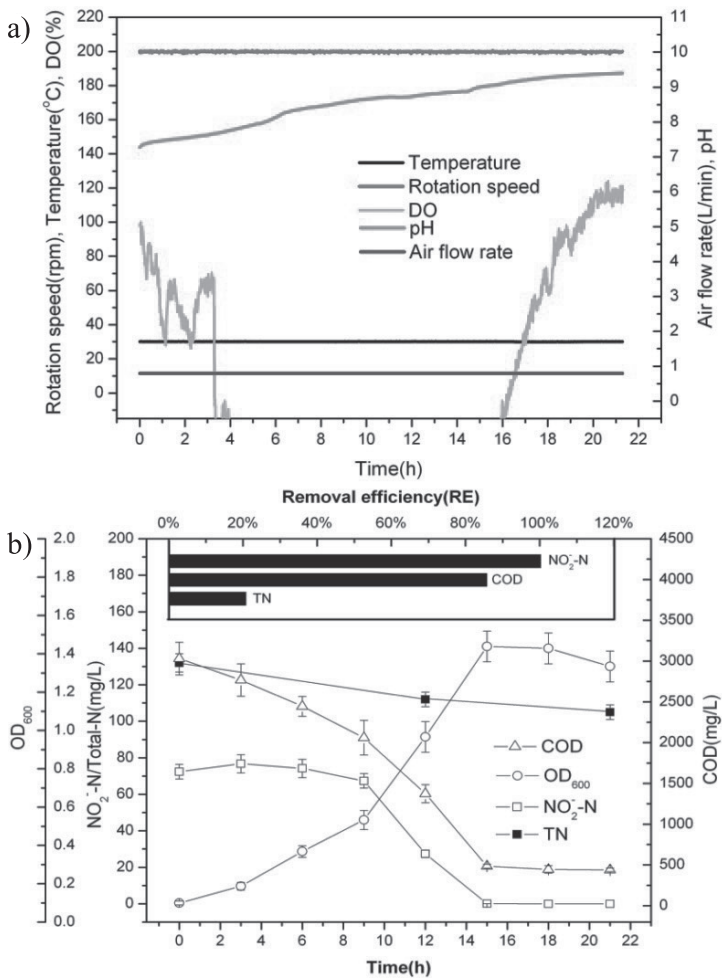

Fig. 4. Nitrite removal by HJH1 in the bioreactor: a) Flow chart including $\mathrm{DO}(\%), \mathrm{pH}$, rotation speed, temperature, and airflow rate; and b) Time courses including $\mathrm{COD}, \mathrm{OD}_{600}$, nitrite, and total nitrogen concentration. conditions tested. It was reported that nitrate removal efficiency was in the order: acetate $>$ glucose $>$ methanol $>$ ethanol, out of which acetate-fed biofilm reduced nearly $100 \%$ nitrate with a negligible amount of nitrite accumulation [26], suggesting that acetate was most favorable for nitrite reductase (NiR). However, a distinct result could be found that the capacity of carbon sources on enhancing NiR enzyme activity follows: methanol $>$ acetate $>$ ethanol on molar basis [27]. In the present study, acetate and glucose seemed to be adverse regarding nitrite removal in HJH1.

At an initial $\mathrm{NO}_{2}^{-}-\mathrm{N}$ concentration of less than $70 \mathrm{mg} / \mathrm{L}$, nitrite decreased to zero (not detected) in $24 \mathrm{~h}$ and the corresponding nitrite removal efficiency was $100 \%$, whereas it was still $15 \mathrm{mg} / \mathrm{L}$ in $30 \mathrm{~h}$ at an initial $\mathrm{NO}_{2}{ }^{-}-\mathrm{N}$ concentration of $90 \mathrm{mg} / \mathrm{L}$ and the corresponding

Table 2. Comparison of denitrification rates in Pseudomonas strains.

\begin{tabular}{|c|c|c|}
\hline Strains & Denitrification rates & References \\
\hline Pseudomonas sp. & $18.2 \mathrm{mg} \mathrm{NO}_{2}^{-}-\mathrm{N} \mathrm{l}^{-1} \mathrm{~d}^{-1}$ & {$[29]$} \\
\hline Pseudomonas putida & $16.2 \mathrm{mg} \mathrm{NO}_{3}^{-}-\mathrm{N} \mathrm{l}^{-1} \mathrm{~d}^{-1}$ & {$[36]$} \\
\hline Pseudomonas stutzeri & $18.14 \mathrm{mg} \mathrm{NO}_{3}^{-}-\mathrm{N} \mathrm{l}^{-1} \mathrm{~d}^{-1}$ & {$[28]$} \\
\hline Pseudomonas putida & $72.4 \mathrm{mg} \mathrm{NO}_{2}^{-}-\mathrm{N} \mathrm{l}^{-1} \mathrm{~d}^{-1}$ & This study \\
\hline
\end{tabular}


Table 3. Nitrogen balance for nitrite removal ${ }^{\mathrm{a}}$ (units: mg/L).

\begin{tabular}{|c|c|c|c|c|c|c|}
\hline Initial TN & $\begin{array}{c}\text { Final } \\
\text { Nitrate-N }\end{array}$ & $\begin{array}{c}\text { Final } \\
\text { Nitrite-N }\end{array}$ & $\begin{array}{c}\text { Final } \\
\text { Ammonium-N }\end{array}$ & $\begin{array}{c}\text { Final } \\
\text { Organic } \mathrm{N}^{\mathrm{b}}\end{array}$ & $\mathrm{N}$ in biomass & $\%_{\text {N } \text { lost }^{\mathrm{d}}}$ \\
\hline $72.4 \pm 1.8$ & $\mathrm{ND}$ & $\mathrm{ND}$ & $\mathrm{ND}$ & $0.8 \pm 0.1$ & $57.1 \pm 0.3$ & 19.6 \\
\hline
\end{tabular}

ND: not detected

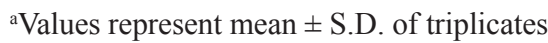

${ }^{\mathrm{b}}$ Calculated value

${ }^{\mathrm{c} B i o m a s s}$ composition was assumed to be $\mathrm{C} 5 \mathrm{H} 7 \mathrm{O} 2 \mathrm{~N}$

$\mathrm{d} \% \mathrm{~N}$ lost $=100 \times\{($ initial TN)$-($ final Nitrate-N)-(final Nitrite-N)-(final ammonium-N)-(final Organic-N)-(N in biomass) $\} /($ initial TN $)$

nitrite removal efficiency was about $83 \%$ (Fig. 3d). With regard to cell density, $30 \mathrm{mg} / \mathrm{L} \mathrm{NO}_{2}^{-}-\mathrm{N}$ was best for cell growth with a maximum $\mathrm{OD}_{600}$ of 0.463 . Generally, the high nitrite concentration has a negative effect on the microorganism, and so far there have been no bacteria reported that could endure such high nitrite concentrations as in this study.

\section{Nitrite Removal by HJH1 in a Bioreactor}

Nitrite removal by HJH1 was carried out in a bioreactor. A flow chart including DO (\%), pH, rotation speed, temperature, and airflow rate was shown in Fig. 4a, and time courses including $\mathrm{COD}, \mathrm{OD}_{600}$, nitrite, and total nitrogen concentration are shown in Fig. 4b. Meanwhile, a detailed nitrogen balance for nitrite removal was carried out (Table 3). Obviously, removal rates for nitrite and COD correlated with the growth rate of stain HJH1, because the fastest removal rates occurred during the log phase. COD concentration decreased from 3,031 to $440 \mathrm{mg} / \mathrm{L}$ and the corresponding removal efficiency was $85.5 \%$. The $\mathrm{NO}_{2}-\mathrm{N}$ concentration decreased from 72.4 to $0 \mathrm{mg} / \mathrm{L}$, and the corresponding denitrification rate was $72.4 \mathrm{mg} \mathrm{NO}_{2}^{-}-\mathrm{N} \mathrm{l}^{-1} \mathrm{~d}^{-1}$, which was much higher than those reported by previous studies (Table 2). It is worth noting that $\mathrm{NO}_{2}^{-}-\mathrm{N}$, as the sole nitrogen source, was consumed completely in $15 \mathrm{~h}$, which was insufficient for further cell growth, thus ending all biological reactions. Considering that cell density reached a maximum value of 1.44 and that approximately $20 \%$ of total nitrogen (Table 3) was converted to nitrogen gas, the intracellular assimilation and extracellular reduction should occur simultaneously. This is in good agreement with the co-respiration of $\mathrm{O}_{2}$ and $\mathrm{NO}_{2}{ }^{-}-\mathrm{N}$ supported in some reports $[7,28,29]$.

The $\mathrm{pH}$ in the suspension elevated gradually from 7.2 to 9.4 , which is consistent with the fact that denitrification is a process with alkaline production [30]. The DO concentration (\%) decreased rapidly from $100 \%$ to $0 \%$ in the first $4 \mathrm{~h}$, and maintained that level for $12 \mathrm{~h}$, after which it increased to $100 \%$ by $20 \mathrm{~h}$. This phenomenon should be attributed to the fast cell growth that respired oxygen rapidly during the log phase. From above, nitrite was also removed primarily during this phase, so it is possible that nitrite respiration was enhanced when DO was not enough, thereby confirming the existence of co-respiration of $\mathrm{O}_{2}$ and $\mathrm{NO}_{2}^{-}-\mathrm{N}$.

\section{Simultaneous Nitrification and Denitrification (SND) by HJH1}

As displayed above, the strain of aerobic denitrification could have heterotrophic nitrification ability. Accordingly, the SND batch experiment was conducted in shaking flasks, and results are shown in Table 4. Obviously, the strain HJH1 has good performance for SND, because ammonium nitrogen decreased rapidly from $80 \mathrm{mg} / \mathrm{l}$ at $0 \mathrm{~h}$ to $31.8 \mathrm{mg} / \mathrm{l}$ at $12 \mathrm{~h}$, and was consumed completely (not detected) at $24 \mathrm{~h}$ with the removal efficiency (RE) being $100 \%$. Meanwhile, the nitrite nitrogen accumulated to $2.55 \mathrm{mg} / \mathrm{l}$ at $9 \mathrm{~h}$, but then it was not detected at $24 \mathrm{~h}$.

Table 4. Simultaneous nitrification and denitrification by HJH1 in flasks.

\begin{tabular}{|c|c|c|c|c|c|}
\hline \multirow{2}{*}{ Time(h) } & \multicolumn{5}{|c|}{ Concentration $(\mathrm{mg} / \mathrm{L})$} \\
\cline { 2 - 6 } & $\mathrm{NH}_{4}{ }^{+}-\mathrm{N}$ & $\mathrm{TN}$ & $\mathrm{COD}$ & $\mathrm{NO}_{2}-\mathrm{N}$ & $\mathrm{NO}_{3}-\mathrm{N}$ \\
\hline 0 & $80 \pm 0.5$ & $80 \pm 4$ & $4021 \pm 227$ & $\mathrm{ND}$ & $\mathrm{ND}$ \\
\hline 6 & $62 \pm 0.8$ & $77 \pm 2.1$ & $3011 \pm 127$ & $0.51 \pm 0.012$ & $\mathrm{ND}$ \\
\hline 9 & $44 \pm 0.7$ & $74 \pm 1.6$ & $2311 \pm 113$ & $2.55 \pm 0.02$ & $\mathrm{ND}$ \\
\hline 12 & $31.8 \pm 0.42$ & $70 \pm 3$ & $869 \pm 84.9$ & $0.61 \pm 0.014$ & $\mathrm{ND}$ \\
\hline 18 & $6.8 \pm 0.2$ & $68 \pm 4.2$ & $386 \pm 18.7$ & $0.10 \pm 0.013$ & $\mathrm{ND}$ \\
\hline 24 & $\mathrm{ND}$ & $67 \pm 3.2$ & $384 \pm 28.3$ & $\mathrm{ND}$ & $\mathrm{ND}$ \\
\hline $\mathrm{RE}(\%)$ & 100 & 17.5 & 90.4 & & \\
\hline
\end{tabular}

ND: not detected 
Table 5. Nitrogen balance for ammonium-N removal ${ }^{\mathrm{a}}$ (units: $\mathrm{mg} / \mathrm{L}$ ).

\begin{tabular}{|c|c|c|c|c|c|c|}
\hline Initial TN & $\begin{array}{c}\text { Final } \\
\text { Nitrate-N }\end{array}$ & $\begin{array}{c}\text { Final } \\
\text { Nitrite-N }\end{array}$ & $\begin{array}{c}\text { Final } \\
\text { Ammonium-N }\end{array}$ & $\begin{array}{c}\text { Final } \\
\text { Organic } \mathrm{N}^{\mathrm{b}}\end{array}$ & ${\mathrm{N} \text { in } \text { biomass }^{\mathrm{c}}}^{\%}$ & ${\text { \% } \text { lost }^{\mathrm{d}}}$ \\
\hline $80.0 \pm 4.0$ & $\mathrm{ND}$ & $\mathrm{ND}$ & $\mathrm{ND}$ & $3.2 \pm 0.19$ & $59.3 \pm 0.24$ & 17.5 \\
\hline
\end{tabular}

ND: not detected

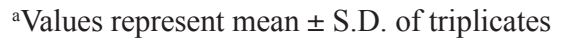

${ }^{\mathrm{b}}$ Calculated value

'Biomass composition was assumed to be $\mathrm{C} 5 \mathrm{H} 7 \mathrm{O} 2 \mathrm{~N}$

d\%N lost $=100 \times\{($ initial TN)-(final Nitrate-N)-(final Nitrite-N)-(final ammonium-N)-(final Organic-N)-(N in biomass) $\} /($ initial TN $)$

Thus total nitrogen (TN) RE was calculated to be $17.5 \%$, which was in good agreement with the nitrogen balance for ammonium-N removal (Table 5).

The data in Table 4 and 5 indicated that strain HJH1 could utilize ammonium to produce nitrite, which is a dominant product generated by ammonia monooxygenase [31] and hydroxylamine oxidoreductase [32]. When the strain HJH1 was cultivated in SNDM, only a trace of nitrite was observed and then not detected, showing that HJH1 might have a high activity of denitrifying enzymes. This phenomenon seems to be in conformance with the data displayed in Fig. 4. All these results confirmed that HJH1 could remove ammonium nitrogen through SND without any nitrite accumulation.

\section{Performance of the SBR}

It is well known that piggery wastewater usually contains high amounts of organic mater and ammonium nitrogen. In order to make $\mathrm{HJH} 1$ accustomed to ammonium surroundings step by step, artificial wastewater was used in stage 1, after piggery wastewater was steadily fed to the SBR in stage 2.

In stage 1 , the average influent concentration of COD was about $550 \mathrm{mg} / \mathrm{L}$ (Fig. 5). On the whole, COD removal increased gradually during this stage, ranging from $71.4 \%$ on day 1 to $100 \%$ on day 10 . Although the

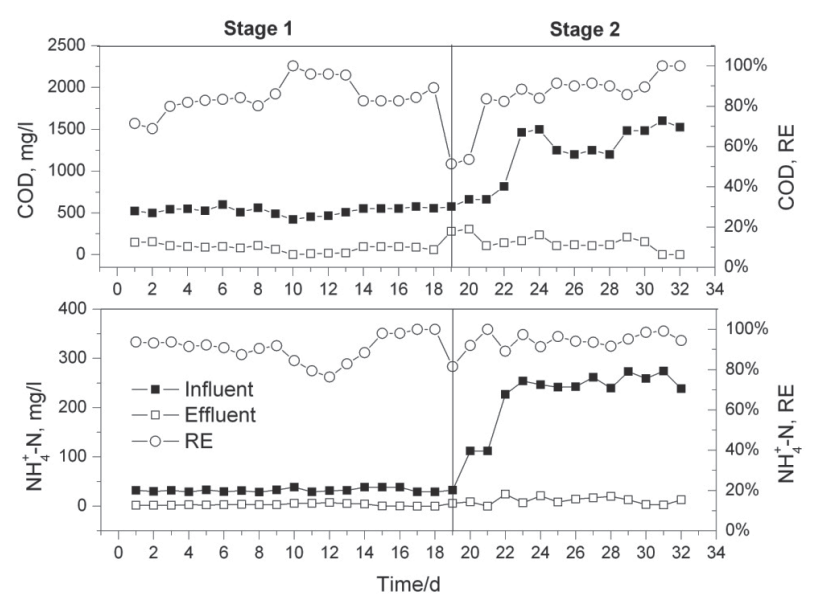

Fig. 5. Pollutant removal in the SBR. The whole operation was composed of two stages: 1) artificial wastewater was fed, and 2) piggery wastewater was fed.
COD RE dropped slightly in the following eight days, the average RE achieved $88.6 \%$. From day 19 on, piggery wastewater was fed in stage 2, and the COD removal sharply decreased to $51.4 \%$, but this phenomenon existed for only a short time. Afterward, the COD RE resumed to normal, and finally to $100 \%$ on days 31 and 32 . In stage 2 , the average influent COD was about $1,500 \mathrm{mg} / \mathrm{l}$, which was obviously much higher than in stage 1 . However, COD removal averaging $92.2 \%$ was maintained in the last eight days.

As far as $\mathrm{NH}_{4}^{+}-\mathrm{N}$ was concerned, a relatively steady RE average of $93.9 \%$ was maintained (except for days 11 to 14 in stage 1), which was different from COD. Although the average influent $\mathrm{NH}_{4}^{+}-\mathrm{N}$ was only about $30 \mathrm{mg} / \mathrm{L}$ during this stage, $\mathrm{NH}_{4}^{+}-\mathrm{N}$ RE decreased from $91.9 \%$ on day 9 to $76.4 \%$ on day 12 , and then increased to $98 \%$ on day 15 . Subsequently, stage 2 started when piggery wastewater was injected into the SBR on day 19 and, similar to COD, the RE of ammonium nitrogen went down to $81.5 \%$, but this trend also lasted for only a short time. In stage 2, the average influent $\mathrm{NH}_{4}{ }^{+} \mathrm{N}$ was about $240 \mathrm{mg} / \mathrm{L}$, which did not exert any influences on its RE. On the contrary, from day 24 , a relatively high RE maintained above $91.4 \%$ and even achieved $99.1 \%$ on day 31 . Moreover, the cyclic profile for pollutant removal on $31 \mathrm{~d}$ was conducted, where $\mathrm{NO}_{2}^{-}-\mathrm{N}$ accumulated $1.08 \mathrm{mg} / \mathrm{L}$ at $1.5 \mathrm{~h}$ and then was not detected at $3.5 \mathrm{~h}$, and pollutants were all removed completely within a few hours (Table 6), suggesting that SND might play an important role in treating piggery wastewater in this SBR.

As mentioned previously, both $\mathrm{COD}$ and $\mathrm{NH}_{4}{ }^{+} \mathrm{N}$ REs presented a remarkable fluctuation during days 10 to 14 . This result probably was ascribed to the following facts. Initially, the pure P. putida was inoculated to the SBR, and all pollutants were entirely degraded by $P$. putida. However, with time elapsing, some bacteria appeared in the SBR (see section 3.6) and functioned together with P. putida to resume REs back to a steady state, which is similar to our previous study [33]. As illustrated in Fig. 5 , although the piggery wastewater fed to the reactor was diluted on day 19 , REs dropped abruptly due to a totally different loading, and recovered rapidly when faced to the raw piggery wastewater. This was mainly because P. putida might have a good adaptability to piggery wastewater. Most importantly, both nitrite and nitrate were not detected in the effluent (Fig. 5), which was in good agreement with the above results that $P$. putida possesses 
Table 6. Cyclic profile for pollutant removal on 31d.

\begin{tabular}{|c|c|c|c|c|}
\hline \multirow{2}{*}{ Time (h) } & \multicolumn{4}{|c|}{ Item $(\mathrm{mg} / \mathrm{L})$} \\
\cline { 2 - 5 } & $\mathrm{NH}_{4}^{+}-\mathrm{N}$ & $\mathrm{NO}_{2}{ }^{-}-\mathrm{N}$ & $\mathrm{NO}_{3}^{-}-\mathrm{N}$ & $\mathrm{COD}$ \\
\hline 0 & $274.5 \pm 2.1$ & $\mathrm{ND}$ & $\mathrm{ND}$ & $1,604 \pm 80.2$ \\
\hline 1.5 & $29.5 \pm 2.6$ & 1.08 & $\mathrm{ND}$ & $225.3 \pm 17.1$ \\
\hline 2.5 & $5.3 \pm 0.92$ & 0.014 & $\mathrm{ND}$ & $61.4 \pm 2.0$ \\
\hline 3.5 & $2.55 \pm 0.06$ & $\mathrm{ND}$ & $\mathrm{ND}$ & $\mathrm{ND}$ \\
\hline 4.5 & $2.60 \pm 0.08$ & $\mathrm{ND}$ & $\mathrm{ND}$ & $\mathrm{ND}$ \\
\hline
\end{tabular}

ND: not detected

a good performance of aerobic denitrification (Fig. 4) and SND (Table 4) without any nitrite accumulation. Nitrite is critical for nitrogen removal because a significant amount of nitrite is the premise for the subsequent denitrification, so the stability of nitrite accumulation was investigated in a sequencing batch reactor [16]. In addition, it has been reported that some factors such as $\mathrm{pH}$ [17], carbon source [15], and temperature [34] affected nitrite accumulation in the treatment of piggery wastewater, which seems to be contradictory to the results in the current study. However, considering that $P$. putida could reduce nitrite rapidly (Fig. 4 ), it would be reasonable if this strain predominates in the SBR.

\section{Stability of HJH1 in the SBR}

For the purpose of analyzing the stability of $P$. putida HJH1 during the whole operation, PCR-DGGE was carried

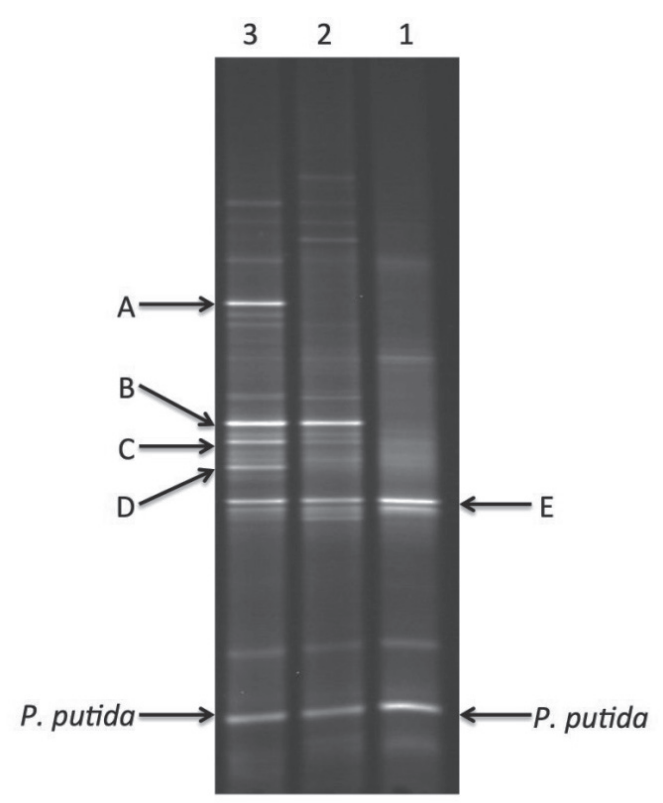

Fig. 6. DGGE profile of PCR-amplified 16S rDNA fragment. Fragments were obtained with bacterial primer set and DNA isolated from active sludge. Lane 1: active sludge of $8 \mathrm{~d}$, Lane 2: active sludge of $16 \mathrm{~d}$, and Lane 3: active sludge of $32 \mathrm{~d}$. out on active sludge of $8 \mathrm{~d}, 16 \mathrm{~d}$, and $32 \mathrm{~d}$, and results are displayed in Fig. 6. Clearly, HJH1 predominated in the SBR all the time, especially in the lane of $8 \mathrm{~d}$. Though some other strains existed on day 16 , the nitrogen removal was conducted mainly by strains B, E, and HJH1. Compared with lane $16 \mathrm{~d}$, some new stains A, C, and D appeared in lane $32 \mathrm{~d}$ due to piggery wastewater. The strain $P$. putida HJH1, however, still inhabited the reactor to function together with other bacteria.

It is very common to use the SBR to treat piggery wastewater, and results revealed that some important functional microorganisms such as ammonium oxidation bacteria (AOB), nitrite oxidation bacteria (NOB), and denitrifiers are required. Meng and coworkers treated piggery wastewater with an upflow microaerobic sludge reactor (UMSR) and found that ammonium oxidation bacteria, heterotrophic denitrifiers, autotrophic denitrifiers, and phosphate-accumulating organisms coexisted perfectly in the system [11]. Furthermore, some other unknown and as yet uncultured microorganisms [12] and algae [35] were significant for the nitrogen removal from piggery wastewater. In the present study, as exhibited in Fig. 6, some microorganisms were also detected, but $P$. putida HJH1 predominated in both stage 1 and 2, which undoubtedly consolidated the results in section 3.5.

\section{Conclusions}

The general results of the present study demonstrate that the ammonium nitrogen of piggery wastewater could be effectively removed by SBR inoculated with Pseudomonas putida HJH1. The SBR system was able to remove $89.2-99.1 \%$ ammonium nitrogen and $82.4-100 \%$ COD from piggery wastewater. Although many bacteria existed, Pseudomonas putida $\mathrm{HJH} 1$ predominated and cooperated with those strains to remove ammonium nitrogen and COD in the reactor. Overall, the results presented and discussed herein obviously indicate that using the SBR system inoculated with Pseudomonas putida HJH1 to treat piggery wastewater is practically feasible.

\section{Acknowledgements}

This research was financially supported by the National Natural Science Foundation of China (grant No. 21407024) and the Fujian Science and Technolgy Department (grant No. 2015J01594).

\section{References}

1. TOMASSO J.R. Comparative toxicity of nitrite to freshwater fishes. Aquat. Toxicol. 8 (2), 129, 1986.

2. JENSEN F.B. Nitrite disrupts multiple physiological functions in aquatic animals. Comparative Biochemistry and Physiology Part A: Molecular \& Integrative Physiology 135 (1), 9, 2003. 
3. GUO Z., ZHENG Z., GU C., ZHENG Y. Gamma irradiationinduced removal of low-concentration nitrite in aqueous solution. Radiat. Phys. Chem. 77 (6), 702, 2008.

4. BOGOCZEK R., KOCIOŁEK-BALAWEJDER E., STANISŁAWSKA E. A macromolecular oxidant, the N,Ndichlorosulfonamide for removal of residual nitrites from aqueous media. React. Funct. Polym. 66 (6), 609, 2006.

5. CESAR A., ROŠ M. Long-term study of nitrate, nitrite and pesticide removal from groundwater: A two-stage biological process. Int. Biodeterior. Biodegrad. 82, 117, 2013.

6. WANG P., LI X., XIANG M., ZHAI Q. Characterization of efficient aerobic denitrifiers isolated from two different sequencing batch reactors by $16 \mathrm{~S}-\mathrm{rRNA}$ analysis. J. Biosci. Bioeng. 103 (6), 563, 2007.

7. ROBERTSON L.A.,KUENEN J.G. Aerobic denitrification: a controversy revived. Arch. Microbiol. 139 (4), 351, 1984.

8. ZHANG J., WU P., HAO B., YU Z. Heterotrophic nitrification and aerobic denitrification by the bacterium Pseudomonas stutzeri YZN-001. Bioresour. Technol. 102, 9866, 2011.

9. OZEKI S., BABA I., TAKAYA N., SHOUN H. A novel C1-using denitrifier Alcaligenes $s p$. STC1 and its genes for copper-containing nitrite reductase and azurin. Biosci. Biotechnol. Biochem. 65 (5), 1206, 2001.

10. KIM J., PARK K., CHO K., NAM S., PARK T., BAJPAI R. Aerobic nitrification-denitrification by heterotrophic Bacillus strains. Bioresour. Technol. 96 (17), 1897, 2005.

11. MENG J., LI J.L., LI J.Z., SUN K., ANTWI P., DENG K.W., WANG C., BUELNA G. Efficiency and bacterial populations related to pollutant removal in an upflow microaerobic sludge reactor treating manure-free piggery wastewater with low COD/TN ratio. Bioresour. Technol. 201, 2016.

12. PATIL S.S., KUMAR M.S., BALLA.S. Microbial community dynamics in anaerobic bioreactors and algal tanks treating piggery wastewater. Appl. Microbiol. Biotechnol. 87 (1), 2010.

13. PRADO N., OCHOA J., AMRANE A. Zero Nuisance Piggeries: Long-term performance of MBR (membrane bioreactor) for dilute swine wastewater treatment using submerged membrane bioreactor in semi-industrial scale. Water Res. 43 (6), 2009.

14. MENG J., LI J.L., LI J.Z., ANTWI P., DENG K.W., WANG C., BUELNA G. Nitrogen removal from low $\mathrm{COD} / \mathrm{TN}$ ratio manure-free piggery wastewater within an upflow microaerobic sludge reactor. Bioresour. Technol. 198, 2015.

15. OBAJA D., MACE S., MATA-ALVAREZ J. Biological nutrient removal by a sequencing batch reactor (SBR) using an internal organic carbon source in digested piggery wastewater. Bioresour. Technol. 96 (1), 2005.

16. WANG L.A., ZHU J., MILLER C. The Stability of Accumulating Nitrite from Swine Wastewater in a Sequencing Batch Reactor. Appl. Biochem. Biotechnol. 163 (3), 2011.

17. YAN L.L., LIU Y., REN Y., WANG X.H., LIANG H.J., ZHANG Y. The Effect of $\mathrm{pH}$ on the Efficiency of an SBR Processing Piggery Wastewater. Biotechnol. Bioprocess Eng. 18 (6), 2013.

18. SU J.J., CHANG Y.C., HUANG S.M. Ammonium reduction from piggery wastewater using immobilized ammoniumreducing bacteria with a full-scale sequencing batch reactor on farm. Water Sci. Technol. 69 (4), 2014.

19. ZHAO B., HE Y.L., HUGHES J., ZHANG X.F. Heterotrophic nitrogen removal by a newly isolated Acinetobacter calcoaceticus HNR. Bioresour. Technol. 101 (14), 2010.
20. GUO Y., ZHOU X.M., LI Y.G., LI K., WANG C.X., LIU J.F., YAN D.J., LIU Y.L., YANG D.H., XING J.M. Heterotrophic nitrification and aerobic denitrification by a novel Halomonas campisalis. Biotechnol. Lett. 35 (12), 2013.

21. YANG Y., HUANG S., ZHANG Y., XU F. Nitrogen Removal by Chelatococcus daeguensis TAD1 and Its Denitrification Gene Identification. Appl. Biochem. Biotechnol. 172 (2), 829, 2014.

22. JIANG R., HUANG S., CHOW A., YANG J. Nitric oxide removal from flue gas with a biotrickling filter using Pseudomonas putida. J. Hazard. Mater. 164 (2-3), 432, 2009.

23. KIM M., JEONG S.-Y., YOON S.J., CHO S.J., KIM Y.H., KIM M.J., RYU E.Y., LEE S.-J. Aerobic Denitrification of Pseudomonas putida AD-21 at Different C/N Ratios. J. Biosci. Bioeng. 106 (5), 498, 2008.

24. APHA, Standard Methods for the Examination of Water and Wastewater, $18^{\text {th }}$ ed. 1992, Washington, DC: American Public Health Association.

25. CYPLIK P., JUZWA W., MARECIK R., POWIERSKACZARNY J., PIOTROWSKA-CYPLIK A., CZARNY J., DROŻDŻYŃSKA A., CHRZANOWSKI Ł. Denitrification of industrial wastewater: Influence of glycerol addition on metabolic activity and community shifts in a microbial consortium. Chemosphere 93 (11), 2823, 2013.

26. SRINANDAN C.S., D'SOUZA G., SRIVASTAVA N., NAYAK B.B., NERURKAR A.S. Carbon sources influence the nitrate removal activity, community structure and biofilm architecture. Bioresour. Technol. 117, 292, 2012.

27. ADAV S.S., LEE D.J., LAI J.Y. Enhanced biological denitrification of high concentration of nitrite with supplementary carbon source. Appl. Microbiol. Biotechnol. 85 (3), 773, 2010.

28. TAKAYA N., CATALAN-SAKAIRI M.A.B., SAKAGUCHI Y., KATO I., ZHOU Z., SHOUN H. Aerobic denitrifying bacteria that produce low levels of nitrous oxide. Appl. Environ. Microbiol. 69 (6), 3152, 2003.

29. WAN C., YANG X., LEE D.J., DU M., WAN F., CHEN C. Aerobic denitrification by novel isolated strain using $\mathrm{NO}_{2}^{-}-\mathrm{N}$ as nitrogen source. Bioresour. Technol. 102, 7244, 2011.

30. FELEKE Z., ARAKI K., SAKAKIBARA Y., WATANABE T., KURODA M. Selective reduction of nitrate to nitrogen gas in a biofilm-electrode reactor. Water Res. 32 (9), 2728, 1998.

31. GILCH S., MEYER O., SCHMIDT I. A soluble form of ammonia monooxygenase in Nitrosomonas europaea. Biol. Chem. 390 (9), 2009.

32. FERNANDEZ M.L., ESTRIN D.A., BARI S.E. Theoretical insight into the hydroxylamine oxidoreductase mechanism. J. Inorg. Biochem. 102 (7), 2008.

33. YANG Y., HUANG S., LIANG W., ZHANG Y., HUANG H., XU F. Microbial removal of NOx at high temperature by a novel aerobic strain Chelatococcus daeguensis TAD1 in a biotrickling filter. J. Hazard. Mater. 203-204, 326, 2012.

34. OBAJA D., MACE S., COSTA J., SANS C., MATAALVAREZ J. Nitrification, denitrification and biological phosphorus removal in piggery wastewater using a sequencing batch reactor. Bioresour. Technol. 87 (1), 2003.

35. WANG Y., GUO W.Q., YEN H.W., HO S.H., LO Y.C., CHENG C.L., REN N.Q., CHANG J.S. Cultivation of Chlorella vulgaris JSC-6 with swine wastewater for simultaneous nutrient/COD removal and carbohydrate production. Bioresour. Technol. 198, 2015.

36. XIANG M.F., WANG P., LIU X.T., ZHAI Q. Selection and identification of aerobic denitrifiers in denitrification process of wastewater. Food Science and Technology 31, 153, 2006. 